\title{
PERANCANGAN MODEL TATA LETAK GUDANG BAHAN BAKU DENGAN METODE CLASS BASED STORAGE DAN SIMULASI PROMODEL
}

\author{
Winnie Septiani, Astrin Ega Dahana dan Sucipto Adisuwiryo \\ Jurusan Teknik Industri, Fakultas Teknologi Industri, Universitas Trisakti \\ e-mail: winnie_septiani@yahoo.com
}

\begin{abstract}
ABSTRAK
PT. Wijaya Karya (WIKA) Industri Energi merupakan Badan Usaha Milik Negara (BUMN) yang memproduksi produk berbasis pemanas air. Permasalahan yang teridentifikasi di gudang bahan baku saat ini adalah keterlambatan pengiriman bahan baku ke lantai produksi yang disebabkan karena waktu perpindahan bahan baku yang besar. Penyebab utama permasalahan ini adalah peletakan bahan baku di gudang yang tidak teratur. Penelitian ini bertujuan merancang model perbaikan tata letak gudang untuk meminimasi waktu perpindahan. Metode yang digunakan dalam penelitian adalah metode class based storage dan simulasi Promodel. Perbaikan tata letak gudang dilakukan dengan mempertimbangkan pengurutan aktivitas, pembentukan kelas, rak penyimpanan dan luas gudang saat ini. Perancangan tata letak gudang dengan metode class based storage diperoleh tiga usulan tata letak. Evaluasi hasil rancangan dimulai dengan mengevaluasi tata letak gudang bahan baku awal. Ketiga usulan perbaikan tata letak gudang baku tersebut kemudian disimulasikan dengan menggunakan Promodel kemudian di verifikasi dan validasi. Usulan 3 merupakan usulan tata letak terbaik karena memiliki waktu perpindahan yang terkecil. Pada tata letak usulan 3 rak kabel dan rak bahan kimia ditukar penempatannya karena dari hasil perhitungan presentase pemakaian rak bahan kimia memiliki presentase pemakaian yang lebih tinggi dibandingkan dengan rak kabel sehingga lebih baik diletakkan yang mendekati pintu I/O. Peletakkan rak penyimpanan material buku, cover enamel, karton pada usulan 3 juga mengalami perpindahan dari keadaan tata letak awal. Hasil rancangan ini diharapkan dapat membantu perusahaan dalam menangani permasalahan tata letak gudangnya.
\end{abstract}

Kata Kunci: tata letak gudang, simulasi, promodel

\begin{abstract}
PT. Wijaya Karya (WIKA) Energy Industry is a State-Owned Enterprise (BUMN) that manufactures water heater based products. The problem identified in the current raw material warehouse is the delay in sending raw materials to the production floor due to the large transfer time of raw materials. The main cause of this problem is laying raw materials in irregular warehouses. This study aims to design a warehouse layout improvement model to minimize displacement time. The method used in this research is the class based storage and simulation model. The improvement of the warehouse layout is carried out by considering sequencing activities, class formation, storage shelves and warehouse area at present. The design of the warehouse layout with the class based storage method obtained three layout proposals. Evaluation of design results begins by evaluating the initial raw material warehouse layout. The three proposals for improving the warehouse layout of raw materials are simulated using Promodel, then verification and validation are carried out. The $3^{\text {rd }}$ proposal is the best layout proposal because it has the smallest transfer time. In the layout of $3^{\text {rd }}$ proposal, the cable rack and chemical rack are exchanged because the calculation of the percentage usage of the chemical rack has a higher then the cable rack so that it is better placed near the I / O door. The placement of the book material storage rack, enamel cover, cardboard in the $3^{\text {rd }}$ proposal also has displacement from the initial layout state. The results of this design are expected to help the company in handling the problem of the warehouse layout.
\end{abstract}

Keywords: warehouse layout, simulation, promodel

\section{PENDAHULUAN}

PT. Wijaya Karya (WIKA) Industri Energi merupakan Badan Usaha Milik Negara (BUMN) sebagai salah satu anak perusahaan dari PT. Wijaya Karya Group yang memiliki proses produksi terintegrasi dimana proses produksi yang dilakukan dari awal pengolahan bahan baku hingga menjadi produk jadi. Berdasarkan hasil pengamatan yang dilakukan pada PT. Wijaya Karya (WIKA) Industri Energi teridentifikasi permasalahan sistem peletakkan bahan baku yang kurang efisien yang menyebabkan operator harus membongkar terlebih dahulu bahan baku yang akan diambil 
kemudian meletakkan kembali bahan baku yang tidak dibutuhkan sehingga membutuhkan waktu yang lama dalam pengambilan bahan baku. Hal ini menyebabkan keterlambatan dalam proses pengambilan bahan baku. Selain metode peletakkan yang kurang efisien, bahan baku yang terdapat pada gudang tersebut belum dikelompokkan sesuai dengan jenis dan ukuran sehingga menyebabkan operator kesulitan dalam mencari bahan baku. PT. Wijaya Karya (WIKA) Industri Energi menetapkan waktu pengambilan bahan baku selama dua jam pada pukul 08.00-10.00. Namun dalam pelaksanaannya, proses pengambilan bahan baku tersebut sering mengalami keterlambatan.

Berdasarkan uraian permasalahan tersebut, penelitian ini bertujuan untuk merancang model perbaikan tata letak gudang untuk meminimasi waktu perpindahan sehingga lebih efisien dan tidak ada waktu yang terbuang karena waktu proses pengambilan bahan baku yang terlalu lama.

\section{METODE PENELITIAN}

Pendekatan yang digunakan untuk perbaikan tata letak gudang bahan baku adalah metode Class Based Storage sedangkan evaluasi hasil perbaikan akan dilakukan dengan menggunakan simulasi Promodel. Metode Class Based Storage merupakan kebijakan penyimpanan yang membagi menjadi beberapa kelas yang sesuai dengan jenis bahan baku yang terdapat pada gudang. Perbaikan sistem tata letak gudang dilakukan dengan memanfaatkan rak penyimpanan yang tidak terpakai dan dengan menggunakan metode Class Based Storage. Metode ini bertujuan untuk meminimalisasi jarak perpindahan bahan dan meminimalisasi biaya pemindahan bahan di gudang. Class Based Storage merupakan kebijakan penyimpanan yang membagi menjadi tiga kelas A, B, dan C berdasarkan pada hukum Pareto dengan memperhatikan level aktivitas storage dan retrieval (S/R) dalam gudang, yaitu 80\% aktivitas S/R diberikan pada $20 \%$ dari item, $15 \%$ pada $30 \%$ dari item dan yang terakhir 5\% aktivitas S/R diberikan pada 50\% [1]][2]. Klasifikasi barang dilakukan menjadi tiga kelas A, B, C yang tergantung dari tingkat $\mathrm{S} / \mathrm{R}$ yang dihasilkannya.
Popularity merupakan prinsip peletakkan item yang memiliki accessibility terbesar di dekat titik Input-Output [3]. Metode ini telah digunakan untuk menentukan faktor keputusan yang terpenting yang dapat dipertimbangkan dalam desain tata letak [4]. Hasilnya menunjukkan bahwa dengan kebijakan penyimpanan berdasarkan pengelompokkan kelas, dapat menurunkan jarak perpindahan. Selain itu, metode ini juga digunakan untuk merancang perbaikan tata letak gudang bahan baku dalam meningkatkan utilitas kapasitas gudang dan percepatan pemenuhan permintaan, penelitian dilakukan dengan mengurutkan jumlah permintaan [5]. Metode ini menganalisis kelebihan persediaan yang menyebabkan barang disimpan di luar blok penyimpanan sehingga akan berpengaruh terhadap aktivitas gudang terutama aktivitas pengambilan barang yang memiliki waktu yang lebih lama [6] metode ini juga digunakan untuk perancangan gudang bahan baku dengan gang yang bersilangan [7].

Pada penelitian ini metode Class Based Storage dimulai dengan pengelompokkan bahan baku, menghitung frekuensi perpindahan jumlah material yang masuk, menghitung jumlah tempat penyimpanan, menghitung jarak perpindahan material, melakukan perhitungan biaya material handling awal, menyusun urutan aktivitas perpindahan dan pembentukan kelas, perancangan perbaikan tata letak gudang bahan baku dan yang terakhir adalah evaluasi usulan perbaikan tata letak gudang. Teknik pengumpulan data yang digunakan dalam penelitian ini adalah pengamatan langsung di lapangan, untuk mengamati dan mengidentifikasi kondisi tata letak gudang saat ini dan mengukur waktu perpindahan material dan wawancara dengan pihak perusahaan untuk verifikasi rancangan tata letak gudang. Data yang digunakan pada penelitian ini meliputi data tata letak gudang saat ini, data waktu perpindahan, data bahan baku yang disimpan di gudang, data alat material handling yang digunakan berupa jenis, jumlah, ukuran material yang terdapat pada gudang. Gambar 1 merupakan gambar tata letak gudang bahan baku saat ini. 


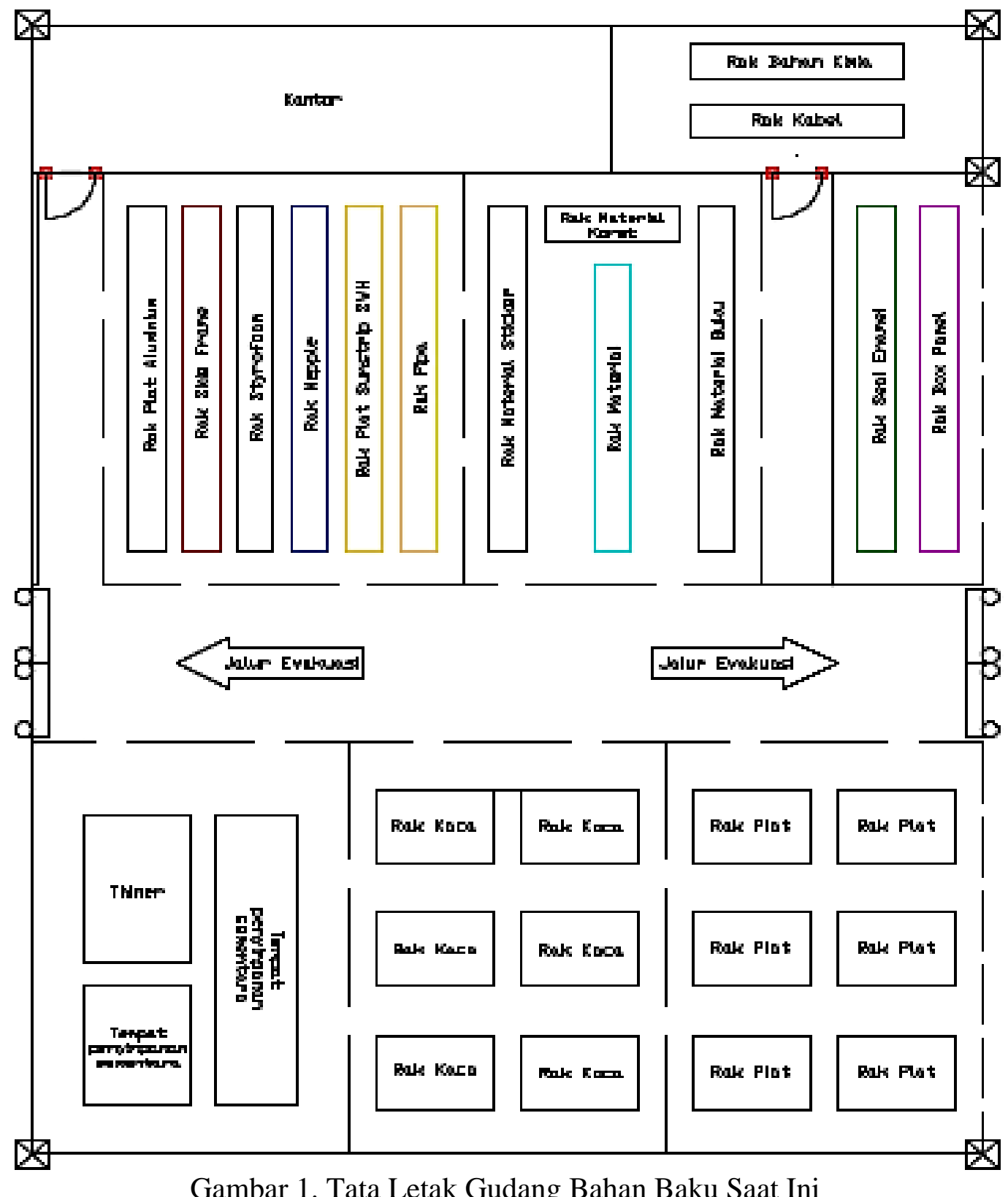

\section{ANALISIS DAN PEMBAHASAN Identifikasi Variabel dalam Sistem}

Pada tahap ini dilakukan identifikasi variabel yang terdapat dalam sistem. Berikut ini merupakan gambaran variabel dalam sistem pada penelitian ini yang dapat dilihat pada Gambar 2.

\section{Model Konseptual}

Model konseptual merupakan hasil pemikiran yang digunakan untuk mengetahui dan menguraikan variabel yang memperngaruhi sistem tersebut. Model konseptual pada penelitian ini dapat dilihat pada Gambar 3.
Sistem Gudang yang diamati meliputi seluruh rak penyimpanan yang digunakan untuk menyimpan bahan baku diantaranya rak cover enamel, rak karton, rak kaca dan sebagainya. Perbaikan tata letak gudang bahan baku ini dipengaruhi oleh karakteristik gudang, jenis bahan baku dan jumlahnya, alat material handling yang digunakan saat ini, jarak perpindahan bahan baku dan waktu perpindahan bahan baku dari rak ke lokasi yang dituju. Evaluasi skenario perbaikan tata letak gudang bahan baku dilakukan dengan menggunakan Simulasi Promodel Indikator kinerja perbaikan sistem diukur berdasarkan total waktu perpindahan dan biaya material handling. 


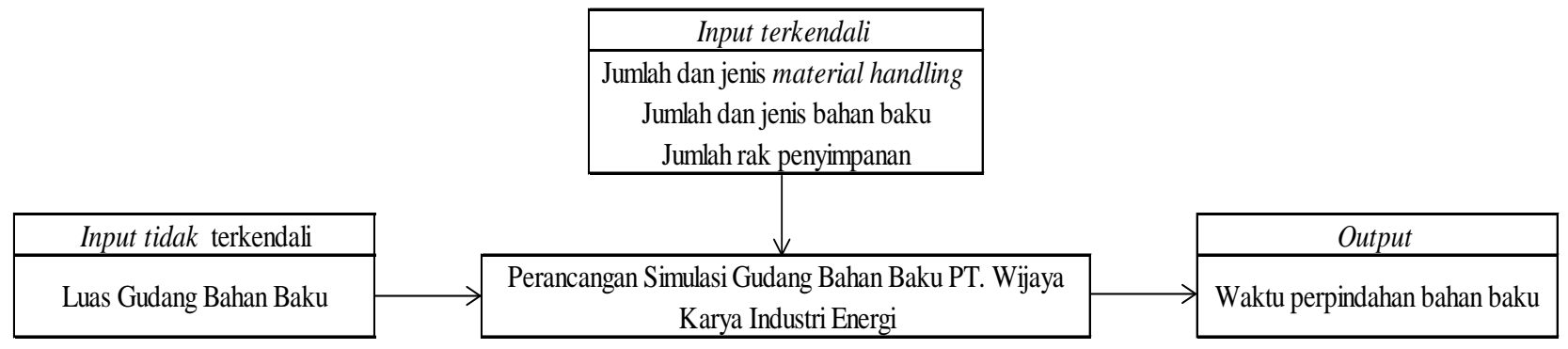

Gambar 2. Variabel dalam Sistem

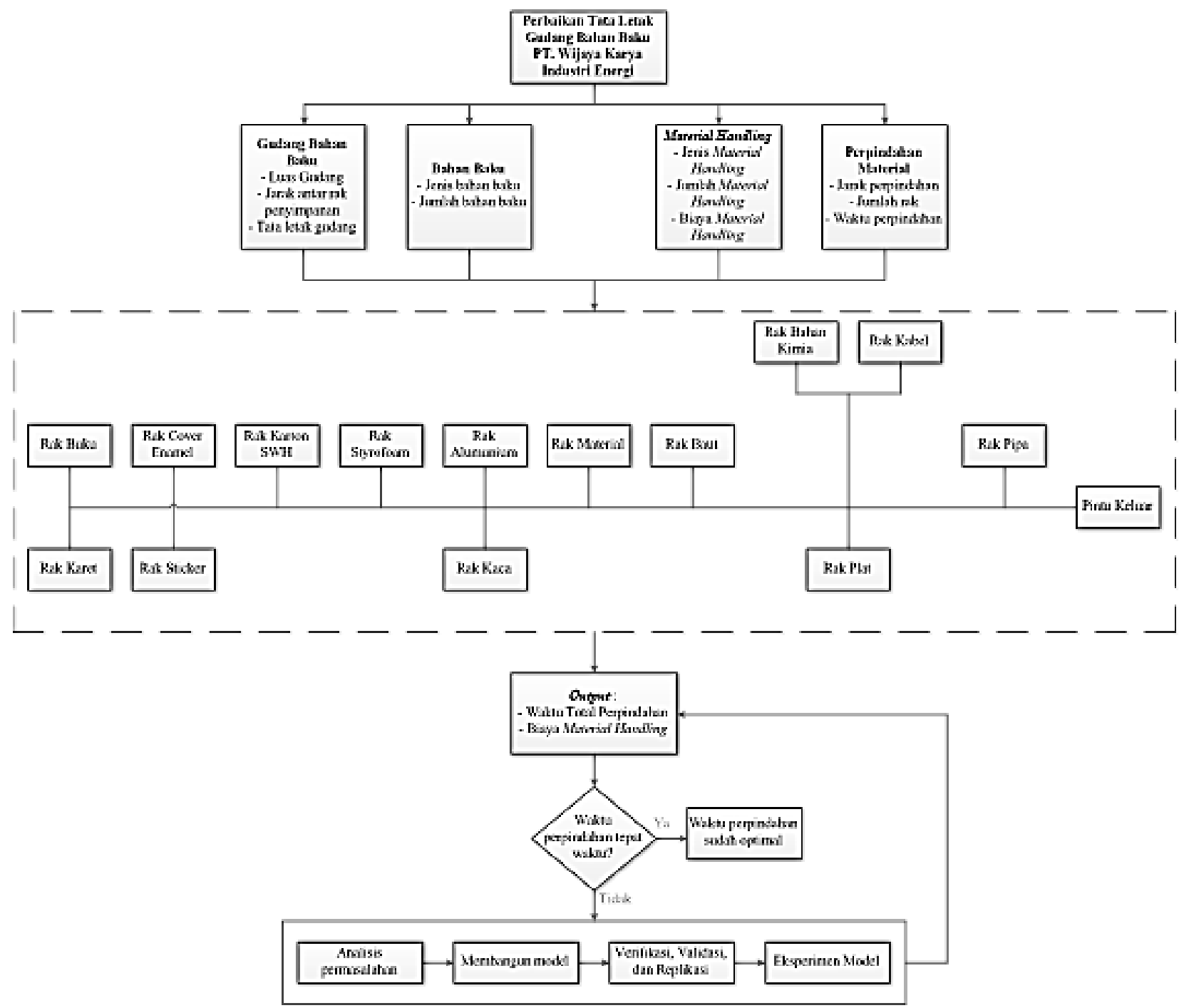

Gambar 3. Model Konseptual.

\section{Model Simulasi}

Pada tahap ini dilakukan converting model konseptual menjadi model simulasi. Elemen-elemen sistem diidentifikasi berdasarkan pembagian elemen struktual pada simulasi Promodel yang terdiri dari entitas, location, arrival, processing, resource dan path network (Gambar 4).

\section{Perbaikan Tata Letak Awal}

Perbaikan tata letak awal dilakukan dengan mengevaluasi tata letak gudang bahan baku dengan memanfaatkan ruang penyimpanan yang tersedia pada area gudang. Pada area gudang terdapat tempat penyimpanan sementara yang digunakan untuk load dan unload barang. Tempat penyimpanan sementara 


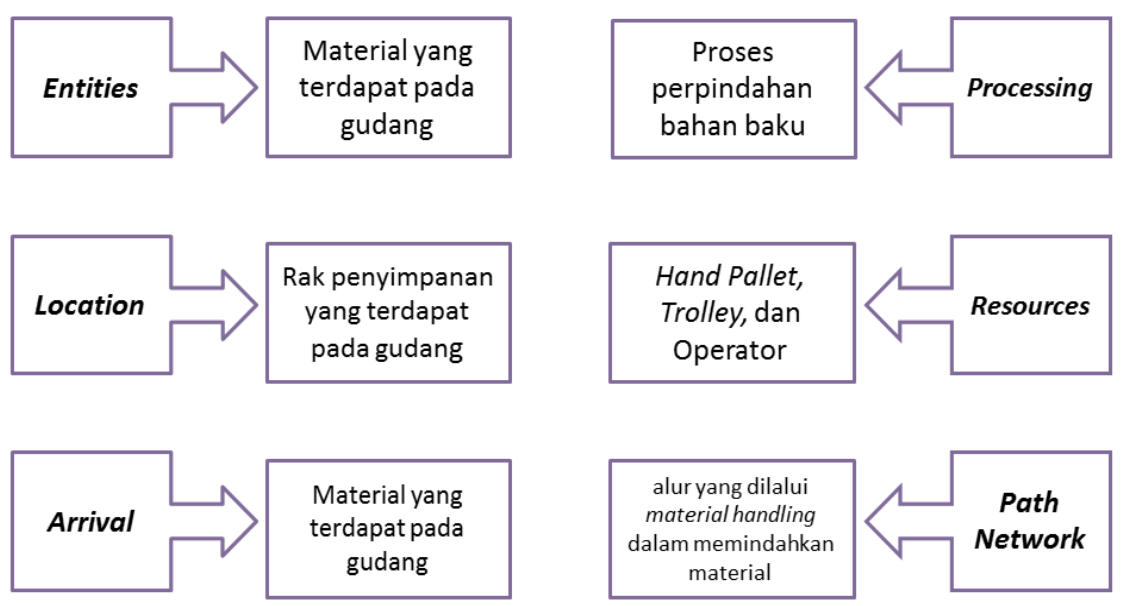

Gambar 4. Model Simulasi Tata Letak Gudang

Tabel 1. Hasil Perhitungan Perbaikan Tata Letak Awal

\begin{tabular}{|c|c|c|c|c|c|c|}
\hline \multirow[b]{2}{*}{$\begin{array}{l}\text { Material } \\
\text { Handling }\end{array}$} & \multicolumn{3}{|c|}{ Tata Letak Awal } & \multicolumn{3}{|c|}{ Tata Letak Perbaikan Awal } \\
\hline & $\begin{array}{c}\text { Sistem } \\
\text { Nyata } \\
\text { (menit) }\end{array}$ & $\begin{array}{c}\text { Simulasi } \\
\text { (menit) }\end{array}$ & Selisih & $\begin{array}{l}\text { Sistem Nyata } \\
\text { (menit) }\end{array}$ & $\begin{array}{c}\text { Simulasi } \\
\text { (menit) }\end{array}$ & Selisih \\
\hline Hand Pallet & 452,48 & 339,33 & 113,15 & 363,41 & $2,935,884$ & 698,216 \\
\hline Trolley & 139,48 & 197,85 & 58,37 & 150,9 & $2,073,876$ & 56,488 \\
\hline Operator & 100,36 & 115,19 & 14,83 & 121,01 & $1,297,716$ & 87,616 \\
\hline Total & 692,32 & 652,37 & & 635,32 & $6,307,476$ & \\
\hline
\end{tabular}

tersebut hanya digunakan untuk menyimpan material sementara pada saat pengecekan material yang baru datang dari supplier. Setelah seluruh material yang baru datang telah selesai dilakukan pengecekan, seluruh material yang terdapat pada tempat penyimpanan sementara didistribusikan ke rak material yang telah ditentukan sehingga tempat penyimpanan sementara tersebut tidak digunakan. Pada perbaikan tata letak awal, tempat penyimpanan sementara akan dimanfaatkan menjadi rak penyimpanan untuk beberapa material. Perbaikan tata letak awal gudang bahan baku dapat dilihat pada Gambar 5.

Hasil perhitungan berdasarkan sistem nyata dan model simulasi yang telah dilakukan waktu perpindahan mengalami perubahan menjadi lebih sedikit. Namun perbaikan tata letak awal belum dapat dikatakan maksimal karena waktu perpindahan bahan baku yang masih melebihi batas yang telah ditetapkan oleh perusahaan. Hasil perhitungan perbaikan tata letak awal dapat dilihat pada Tabel 1.

\section{Perbaikan Tata Letak dengan Menggunakan Class Based Storage}

Tahapan perbaikan tata letak dengan menggunakan class based storage terdiri dari:

- Pengelompokan bahan baku

Pengelompokkan bahan baku dilakukan dengan mengelompokkan bahan baku yang sejenis berdasarkan dimensi bahan baku dan spesifikasi bahan baku.

- Menghitung Frekuensi Perpindahan

Frekuensi perpindahan dihitung dari material yang masuk dan keluar, kapasitas tempat penyimpanan, dan jumlah tempat penyimpanan. Sehingga dapat dihitung banyaknya pallet yang dibutuhkan untuk menyimpan material. Perhitungan frekuensi perpindahan material dapat dilihat pada Tabel 2.

- Menghitung Jumlah Tempat Penyimpanan Perhitungan jumlah tempat penyimpanan yang dibutuhkan didapatkan dari data jumlah maksimal material yang masuk setiap bulannya. Jumlah maksimal material untuk material pipa sebanyak 10170. 
Setelah menghitung kebutuhan tempat penyimpanan, dilanjutkan dengan mengitung kebutuhan luasan penyimpanan (pallet). Hasil Perhitungan jumlah tempat penyimpanan dapat dilihat pada Tabel 3.

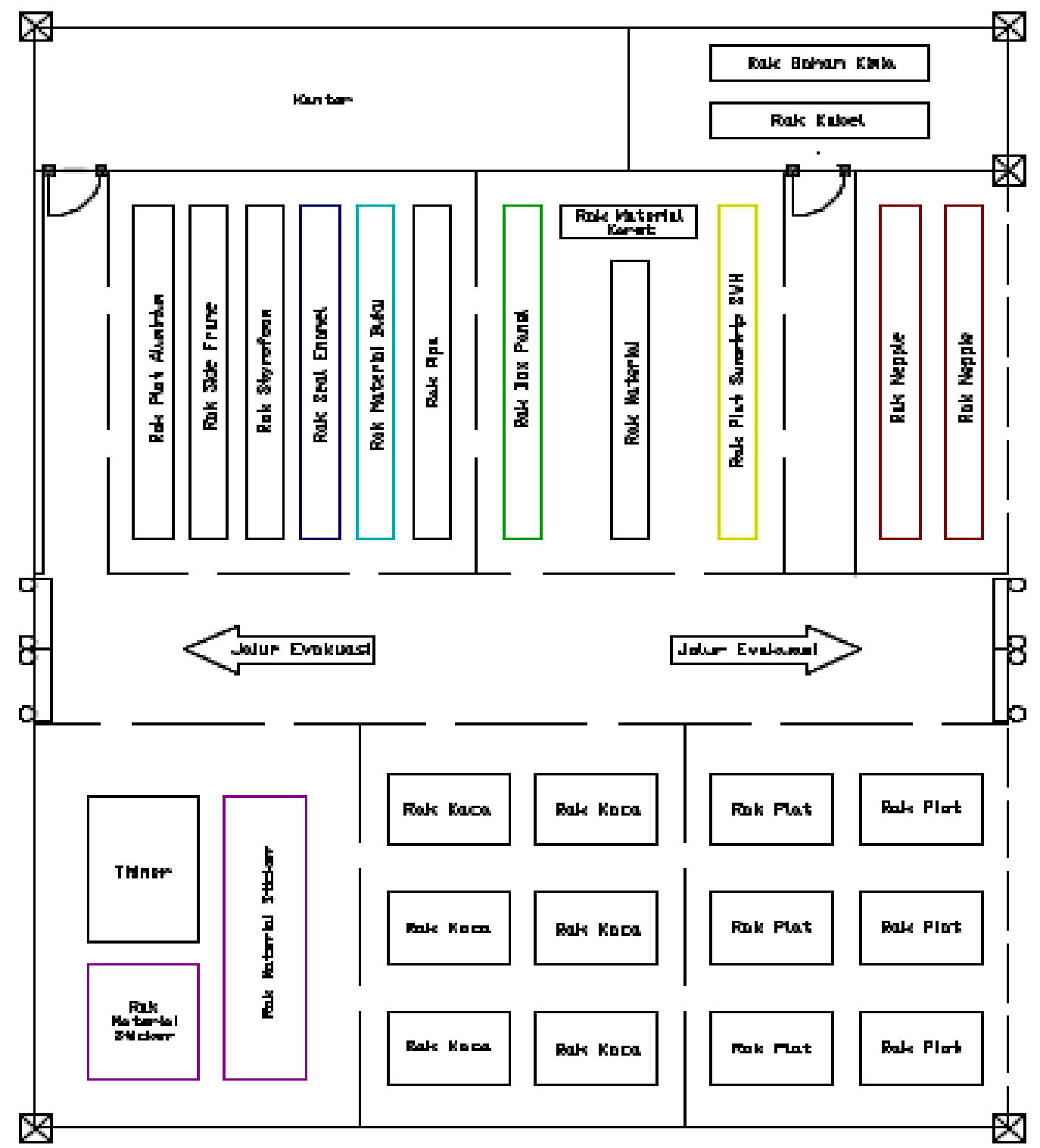

Gambar 5. Usulan 1 Tata Letak Gudang

Tabel 2. Frekuensi Perpindahan Material

\begin{tabular}{clccc}
\hline No. & \multicolumn{1}{c}{ Material } & $\begin{array}{c}\text { Banyak Pallet } \\
\text { Masuk }\end{array}$ & $\begin{array}{c}\text { Banyak Palet } \\
\text { Keluar }\end{array}$ & Total Frekuensi \\
\hline 1 & Pipa & 3,46 & 3,43 & 6,89 \\
2 & Alumunium & 2,30 & 2,24 & 4,54 \\
3 & Material Pendukung & 3,45 & 3,30 & 6,75 \\
4 & Plat & 0,70 & 0,70 & 1,40 \\
5 & Baut & 2,35 & 2,26 & 4,61 \\
6 & Bahan Kimia & 2,35 & 2,31 & 4,67 \\
7 & Kaca & 0,54 & 0,52 & 1,06 \\
8 & Sticker & 1,35 & 1,33 & 2,68 \\
\hline
\end{tabular}


Lanjutan Tabel 2. Frekuensi Perpindahan Material

\begin{tabular}{clccc}
\hline No. & \multicolumn{1}{c}{ Material } & $\begin{array}{c}\text { Banyak Pallet } \\
\text { Masuk }\end{array}$ & $\begin{array}{c}\text { Banyak Palet } \\
\text { Keluar }\end{array}$ & Total Frekuensi \\
\hline 9 & Karet & 1,79 & 1,73 & 3,52 \\
10 & Karton & 1,12 & 1,05 & 2,17 \\
11 & Strofoam & 1,71 & 1,68 & 3,38 \\
12 & Cover & 0,96 & 0,90 & 1,86 \\
13 & Kabel & 2,23 & 2,17 & 4,40 \\
14 & Material Buku & 0,76 & 0,72 & 1,47 \\
15 & Thinner & 0,80 & 0,67 & 1,47 \\
\hline \multicolumn{2}{c}{ Total } & 25,86 & 25,02 & 50,88 \\
\hline
\end{tabular}

Kebutuhan tempat penyimpanan $=\frac{\text { Maksimal in raw material }}{\text { Kapasitas tempat penyimpanan }}$

Kebutuhan luasan penyimpanan $($ pallet $)=\frac{\text { Kebutuhan tempat penyimpanan }}{\text { Tumpukan }}$

Tabel 3. Jumlah Tempat Penyimpanan

\begin{tabular}{|c|c|c|c|c|c|c|}
\hline No. & Material & $\begin{array}{l}\text { Maksimal } \\
\text { In Raw } \\
\text { Material }\end{array}$ & $\begin{array}{c}\text { Kebutuhan } \\
\text { Tempat } \\
\text { Penyimpanan } \\
\text { (Pallet) } \\
\end{array}$ & Tumpukan & $\begin{array}{c}\text { Kebutuhan } \\
\text { Luasan } \\
\text { Penyimpanan } \\
\text { (Pallet) } \\
\end{array}$ & Pemb. \\
\hline 1 & Pipa & 10170 & 9 & 2 & 4,50 & 5,00 \\
\hline 2 & Alumunium & 14040 & 8 & 1 & 8,00 & 8,00 \\
\hline 3 & Material Pendukung & 17107 & 9 & 2 & 4,50 & 5,00 \\
\hline 4 & Plat & 1280 & 1 & 1 & 1,00 & 1,00 \\
\hline 5 & Baut & 15595 & 4 & 1 & 4,00 & 4,00 \\
\hline 6 & Bahan Kimia & 3558 & 3 & 1 & 3,00 & 3,00 \\
\hline 7 & Kaca & 1335 & 4 & 1 & 4,00 & 4,00 \\
\hline 8 & Sticker & 15886 & 4 & 2 & 2,00 & 2,00 \\
\hline 9 & Karet & 6400 & 3 & 2 & 1,50 & 2,00 \\
\hline 10 & Karton & 2880 & 3 & 2 & 1,50 & 2,00 \\
\hline 11 & Strofoam & 11325 & 3 & 1 & 3,00 & 3,00 \\
\hline 12 & Cover & 1566 & 2 & 2 & 1,00 & 1,00 \\
\hline 13 & Kabel & 2495 & 3 & 1 & 3,00 & 3,00 \\
\hline 14 & Material Buku & 1110 & 2 & 2 & 1,00 & 1,00 \\
\hline 15 & Thinner & 90 & 1 & 2 & 0,50 & 1,00 \\
\hline & Total & & 59 & \multicolumn{2}{|c|}{ Total } & 45,00 \\
\hline
\end{tabular}

- Menghitung Jarak Perpindahan Material Perhitungan jarak perpindahan material dilakukan dengan menggunakan metode jarak rectilinier, dengan mengukur jarak titik masuk dan titik keluar dengan titik pusat pada blok penyimpanan dari masingmasing material. Perhitungan jarak perpindahan material dapat dilihat pada Tabel 4.

- Menghitung Biaya Material Handling Awal Perhitungan biaya material handling dengan menggunakan perhitungan MHES. Hasil yang didapat dari perhitungan MHES adalah total biaya perpindahan material. Perhitungan MHES memerlukan informasi 
mengenai jarak rectilinear dan juga alat material handling yang digunakan pada setiap perpindahan material.

\section{Pengurutan Aktivitas Perpindahan dan Pembentukan Kelas}

Pengurutan aktivitas perpindahan dan pembentukan kelas menggunakan jumlah pemakaian material yang didapat dari total frekuensi yang telah dihitung sebelumnya. Setelah dilakukan perhitungan frekuensi pada setiap material dilakukan pengurutan total frekuensi dari total frekuensi yang terbesar hingga total frekuensi terkecil. Pengurutan aktivitas perpindahan dan pembentukan kelas dapat dilihat pada Tabel 5.

Tabel 4. Jarak Perpindahan Material

\begin{tabular}{clccccc}
\hline No. & \multicolumn{1}{c}{ Material } & xi & xj & yi & yj & $\begin{array}{c}\text { Jarak Penyimpanan } \\
(\mathrm{m})\end{array}$ \\
\hline 1 & Pipa & 1 & 1,415 & 5,79 & 1 & 5,21 \\
2 & Alumunium & 1 & 9,84 & 5,79 & 1 & 13,63 \\
3 & Material Pendukung & 1 & 7,01 & 5,195 & 1 & 10,21 \\
4 & Plat & 1 & 3 & 5,83 & 1 & 6,83 \\
5 & Baut & 1 & 5,025 & 5,79 & 1 & 8,82 \\
6 & Bahan Kimia & 1 & 3,505 & 12,25 & 1 & 13,76 \\
7 & Kaca & 1 & 9 & 5,83 & 1 & 12,83 \\
8 & Sticker & 1 & 14,875 & 6,915 & 1 & 19,79 \\
9 & Karet & 1 & 7,01 & 8,945 & 1 & 13,96 \\
10 & Karton & 1 & 15,35 & 5,79 & 1 & 19,14 \\
11 & Strofoam & 1 & 11,7 & 5,79 & 1 & 15,49 \\
12 & Cover & 1 & 12,73 & 5,79 & 1 & 16,52 \\
13 & Kabel & 1 & 3,505 & 11,05 & 1 & 12,56 \\
14 & Material Buku & 1 & 13,76 & 5,79 & 1 & 17,55 \\
15 & Thinner & 1 & 16 & 4,58 & 1 & 18,58 \\
\hline
\end{tabular}

Tabel 5. Pengurutan Aktivitas Perpindahan dan Pembentukan Kelas

\begin{tabular}{clcccc}
\hline No. & \multicolumn{1}{c}{ Material } & $\begin{array}{c}\text { Jumlah } \\
\text { Pemakaian }\end{array}$ & $\begin{array}{c}\text { Persentase } \\
\text { Pemakaian \% }\end{array}$ & $\begin{array}{c}\text { Total Persentase } \\
\text { Pemakaian \% }\end{array}$ & Kelas \\
\hline 1 & Pipa & 6,89 & $13,54 \%$ & & \\
2 & Material Pendukung & 6,75 & $13,27 \%$ & & \\
3 & Bahan Kimia & 4,67 & $9,17 \%$ & & \\
4 & Baut & 4,61 & $9,07 \%$ & $76,20 \%$ & A \\
5 & Aluminium & 4,54 & $8,92 \%$ & & \\
6 & Kabel & 4,40 & $8,66 \%$ & & \\
7 & Karet & $35,196,667$ & $6,92 \%$ & & \\
8 & Styrofoam & 3,38 & $6,65 \%$ & & \\
\hline 9 & Sticker & 2,68 & $5,27 \%$ & & \\
10 & Karton & 2,17 & $4,26 \%$ & & \\
11 & Cover & 1,86 & $3,66 \%$ & & \\
12 & Thinner & 1,47 & $2,89 \%$ & & \\
13 & Material Buku & 1,47 & $2,89 \%$ & $18,96 \%$ & \\
\hline 14 & Plat & 1,40 & $2,75 \%$ & & \\
15 & Kaca & 1,06 & $2,09 \%$ & $4,84 \%$ & \\
\hline \multicolumn{7}{c}{ Total } & 50,88 & $100,00 \%$ & $95,16 \%$ & \\
\hline
\end{tabular}

\section{Tata Letak Gudang Usulan}

Setelah dilakukan pengurutan aktivitas dan pembentukan kelas, selanjutnya merancang tata letak gudang dengan mempertimbangkan luas gudang. Gambar 6 dan 7 merupakan hasil rancangan dua tata letak usulan.

Secara keseluruhan tata letak usulan 2 dan 3 sudah sesuai dengan pengelompokkan kelas 


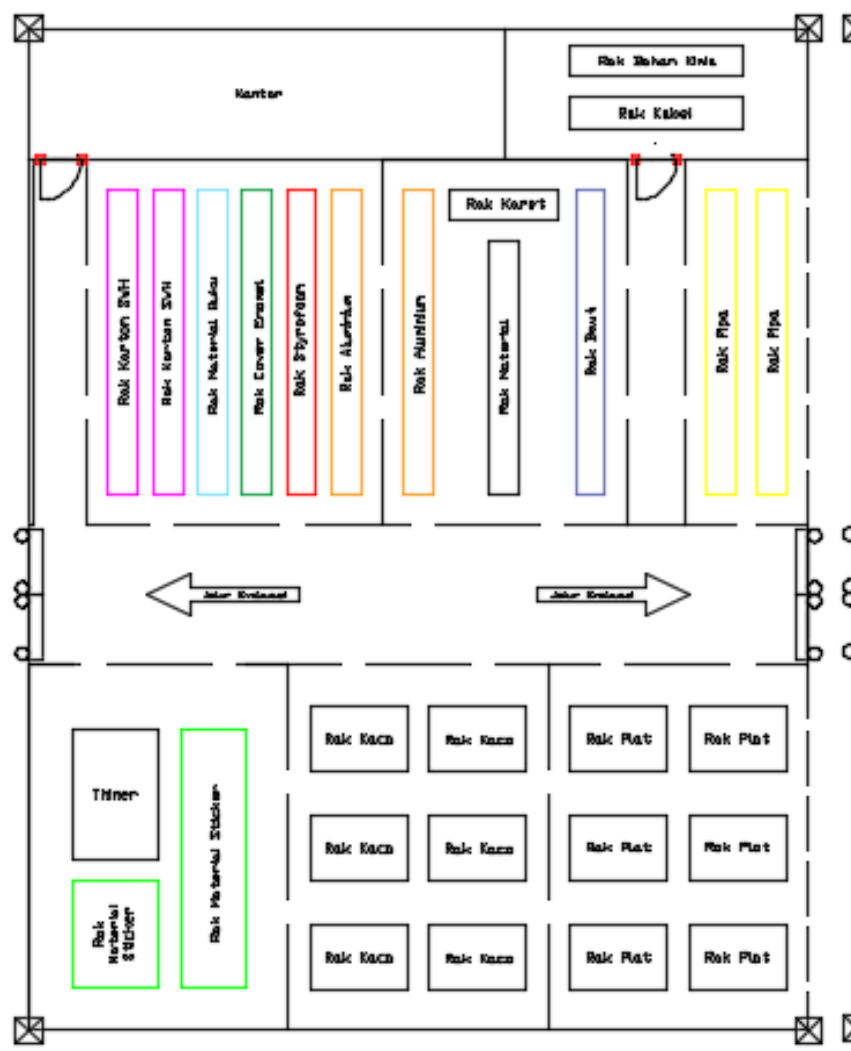

Gambar 6. Usulan 2 Tata Letak Gudang Gambar

berdasarkan hasil perhitungan pada metode Class Based Storage. Pada tata letak usulan 3 rak kabel dan rak bahan kimia ditukar penempatannya karena dari hasil perhitungan presentase pemakaian rak bahan kimia memiliki presentase pemakaian yang lebih tinggi dibandingkan dengan rak kabel sehingga lebih baik diletakkan yang mendekati pintu I/O. Peletakkan rak penyimpanan material buku, cover enamel, karton dilakukan perpindahan dengan alasan yang sama seperti pada rak kabel dan rak kimia yaitu rak karton memiliki hasil perhitungan presentase pemakaian yang lebih tinggi dibandingkan dengan rak cover dan rak material buku.

\section{Evaluasi Hasil Rancangan dengan Simulasi Promodel}

- Verifikasi dan validasi Tata Letak Gudang Usulan

Setelah dihasilkannya tata letak gudang usulan, kemudian tata letak gudang usulan tersebut dibuat model simulasi yang kemudian dilakukan verifikasi model. Dari hasil uji verifikasi, dapat terlihat bahwa

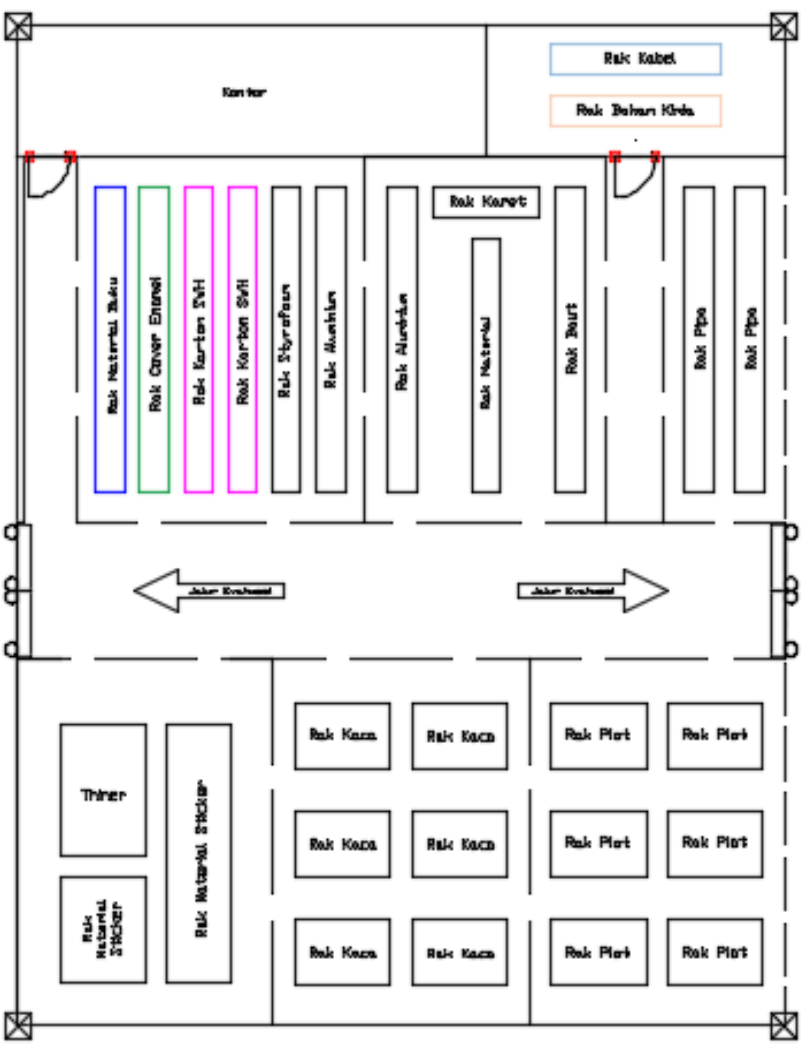

7. Usulan 3 Tata Letak Gudang

model sudah dapat berjalan sesuai dengan proses yang dimaksud oleh pembuat model dan tidak mengalami error.

Sama seperti model awal setelah model simulasi dikatakan terverifikasi selanjutnya dilakukan perhitungan uji validasi. Uji validasi digunakan untuk mengetahui dan untuk memastikan apakah model simulasi sudah merepresentasikan sistem nyata. Perhitungan validasi ini sama halnya dengan model awal yaitu membandingkan waktu sistem nyata dengan waktu simulasi. Hasil perhitungan uji validasi untuk tata letak usulan dapat dilihat pada Tabel 6, 7, dan 8 .

Tabel 6. Validasi Model Simulasi Tata Letak Usulan 1

\begin{tabular}{lccc}
\hline $\begin{array}{l}\text { Material } \\
\text { Handling }\end{array}$ & $\begin{array}{c}\text { Sistem } \\
\text { Nyata } \\
\text { (menit) }\end{array}$ & $\begin{array}{c}\text { Simulasi } \\
\text { (menit) }\end{array}$ & Selisih \\
\hline Hand Pallet & 271,58 & 217,21368 & 54,36632 \\
Trolley & 247,26 & 240,6 & 6,66 \\
Operator & 93,88 & 102,59184 & $-8,71184$ \\
\hline Total & 612,72 & 560,40552 & \\
\hline
\end{tabular}


Tabel 7. Validasi Model Simulasi Tata Letak Usulan 2

\begin{tabular}{lccc}
\hline $\begin{array}{l}\text { Material } \\
\text { Handling }\end{array}$ & $\begin{array}{c}\text { Sistem } \\
\text { Nyata } \\
\text { (menit) }\end{array}$ & $\begin{array}{c}\text { Simulasi } \\
\text { (menit) }\end{array}$ & Selisih \\
\hline Hand Pallet & 271,86 & 244,6266 & 27,2334 \\
Trolley & 217,4 & 235,59576 & $-18,1958$ \\
Operator & 94,69 & 106,48452 & $-11,7945$ \\
\hline Total & 583,95 & 586,70688 & \\
\hline
\end{tabular}

Tabel 8. Uji Validasi Model Simulasi Tata Letak Usulan 1 dan 2

\begin{tabular}{ccc}
\hline \multicolumn{3}{c}{ Validasi } \\
\hline Perhitungan & Usulan 1 & Usulan 2 \\
\hline Rata-rata & $1,743,816$ & 0,91896 \\
SD & $3,289,134$ & $2,458,985$ \\
hw & $8,165,624$ & 610,469 \\
x-hw & 642,181 & 619,659 \\
x+hw & 990,944 & $6,012,794$ \\
t & 4,3 & 4,3 \\
\hline
\end{tabular}

Dari data tabel di atas dapat diambil kesimpulan bahwa kedua model usulan dinyatakan valid karena selang nilai interval memuat angka nol (0).

- Pemilihan Usulan Tata Letak Gudang Terbaik

Dalam penelitian ini terdapat 3 model usulan. Hasil perbandingan model dapat dilihat pada Tabel 9.

Tabel 9. Hasil Perbandingan Model Awal dan Model Usulan

\begin{tabular}{lcc}
\hline \multicolumn{1}{c}{ Model } & $\begin{array}{c}\text { Waktu } \\
\text { Perpindahan } \\
\text { (menit) }\end{array}$ & $\begin{array}{c}\text { Biaya Material } \\
\text { Handling } \\
\text { (Rp) }\end{array}$ \\
\hline Model Awal & 652,37 & 9.277 .224 \\
Model Usulan 1 & 630,75 & 8.455 .859 \\
Model Usulan 2 & 590,15 & 8.109 .316 \\
Model Usulan 3 & 586,71 & 7.743 .131 \\
\hline
\end{tabular}

Berdasarkan tabel di atas model usulan yang dipilih adalah model usulan 3. Model usulan 3 memiliki waktu yang lebih singkat yaitu 586,71 menit dalam seminggu atau jika dihitung dalam sehari waktu perpindahan bahan baku 1,95 jam atau 116,79 menit. Dari hasil tersebut model usulan 3 dapat mencapai target waktu pengambilan bahan baku yang telah ditetapkan oleh perusahaan yaitu selama 2 jam.

\section{KESIMPULAN}

Dari hasil pengolahan dan analisa data maka dapat disimpulkan dari hasil evaluasi dengan menggunakan metode Class Based Storage dapat meminimalkan waktu perpindahan bahan baku. Hasil evaluasi tersebut didapatkan dua model usulan tata letak gudang bahan baku dan dipilih model usulan terbaik adalah model usulan 3. Waktu perpindahan bahan baku berkurang sebanyak 65,66 menit atau persen penurunan sebesar $10,06 \%$. Namun hasil tersebut dapat mencapai target waktu pengambilan bahan baku yang telah ditetapkan oleh perusahaan yaitu selama 2 jam dalam sehari atau 10 jam dalam seminggu. Penelitian selanjutnya dapat dikembangkan indicator kinerja sistem yang lain seperti utilitas. Selain itu skenari perbaikan sistem dapat dikembangkan dengan memperbaiki kapasitas rak dan perbaikan alat material handling.

\section{DAFTAR PUSTAKA}

[1] Yu, Y., Koster, R. B. M. d., dan Guo, X. (2015). Class-Based Storage with a Finite Number of Items: Using More Classes is not Always Better. Production and Operations Management. No. 24, PP. 1235-1247.

[2] Zaerpour, N., Yu, Y., dan Koster, R. B. M. d. (2017). Optimal two-class-based storage in a live-cube compact storage system. IISE Transactions. No. 49, PP. 653-668.

[3] Hadiguna, R. A. dan Setiawan, H. (2008). Tata Letak Pabrik. Penerbit Andi. Yogyakarta

[4] Shqair, M. I. dan Altarazi, S. A., "Layout design of multiple blocks class-based storage strategy warehouses," presented at the International Conference on Industrial Engineering and Operations Management, Bali, 2014.

[5] Hidayat, N. P. A. (2012). Perancangan Tata Letak Gudang dengan Metode Class Based Storage Studi Kasus CV. Jurnal Al-Azhar Indonesia Seri Sains Dan Teknologi. No. 1, PP. 105-115. 
[6] Sujana, A. P., Damayanti, D. D., dan Astuti, M. D. (2014). Usulan Perbaikan Alokasi Penyimpanan Barang dengan Metode Class Based Storage pada Gudang Bahan Baku 1 PT. SMA. (JRSI) Jurnal Rekayasa Sistem dan Industri. No. 1, PP. 1-7.

[7] Accorsi, R., Bortolini, M., Ferrari, E., Gamberi, M., dan Pilati, F. (2018). ClassBased Storage Warehouse Design with Diagonal Cross-Aisle. Log Forum Scientific Journal of Logistics. No. 14, PP. 101-112. 